\title{
Animal genetic resources in Goa: an overview
}

\author{
U. Surati* and D. Paul
}

Animal Genetics and Breeding Division, ICAR-National Dairy Research Institute, Deemed University, Karnal-132001, Haryana, India

*Corresponding author e-mail: utsav.surati@yahoo.com; Ph: +91-8866590445

Journal of Livestock Science (ISSN online 2277-6214) 12: 37-41

Received on 6/8/20; Accepted on 30/11/2020; Published on 5/1/2021

doi. 10.33259/JLivestSci.2021.37-41

\begin{abstract}
Goa is adding valuable contribution to the animal genetic resources with newly registered breeds by National Bureau of Animal Genetic Resources (NBAGR), Karnal. The two cattle breeds 'Konkan Kapila' and 'Shweta Kapila' has exceptional significance for draught and milk purpose respectively. The breed of pig 'Agonda Goan' is good for pork and has exceptional mothering instinct. They are adding strength to the genetic resources of India. This review paper will give an overview of current status of nationally registered animal genetic resources found in Goa with their morphological and economic characteristics.
\end{abstract}

Key words: Animal Genetic Resources; Breeds; Konkan Kapila; Shweta Kapila; Agonda Goan; Goa; India 


\section{Introduction}

India is one of the 17 Mega-biodiversity countries with $2.5 \%$ global land (CI, 1998). It harbours different kinds of ecosystems which include tropical rain forests, high alpine cold deserts, wetlands, grass lands and coastal areas. It is embellished with 10 biogeographic zones. India contributes $7-8 \%$ of the world's species with 45,000 and 81,000 species of plants and animal respectively (Chaudhary et al., 2011). As per the latest livestock census 2019, India has total 535.78 million livestock population and 851.81 million poultry population. Individual contribution is $35.94 \%$ Cattle, $20.45 \%$ Buffaloes, $27.80 \%$ Goat, $13.87 \%$ Sheep, $1.69 \%$ Pigs, $0.23 \%$ by the rest other species (Mithun, Yaks, Horses, Ponies, Mules, Donkeys and Camels) to the total Indian livestock population (Fig 1). Till now, total 197 breeds have been registered by National Bureau of Animal Genetic Resources, Karnal in India, which includes 50 breeds for cattle, 17 for buffalo, 34 for goat, 44 for sheep, 7 for horses \& ponies, 9 for camel, 10 for pig, 3 for donkey, 1 for yak, 19 for chicken, 2 for duck and 1 for geese as represented in the Table 1.

\section{Animal Genetic Resources of Goa}

Goa, western state of India with coastline meeting the Arabian Sea, which is also considered as the smallest state of India by area of about 3702 sq. km (Office of the Registrar General \& Census Commissioner, India, 2020). According to Unique Identification Aadhar India, updated on $31^{\text {st }}$ May, 2020 the human population in Goa is estimated to be 1.58 million. The region is also known as "KONKAN" has rich flora and fauna as it is situated on the Western-Ghats range which is classified as a biodiversity hotspot. Recently their native breeds have been registered by the National Bureau of Animal Genetic Resources, Karnal in India. Now, Goa has three registered breeds of livestock. There are two cattle breeds namely 'Konkan Kapila' and 'Shweta Kapila' and one is pig breed 'Agonda Goan'. Each of them has their unique characteristics and shares a valuable contribution to the animal genetic resources of India. Total population of major livestock species of Goa is represented in the Table 2.

Table 1: Species wise Livestock Population India (NBAGR, 2019 and Livestock census, DAHD, 2019)

\begin{tabular}{|l|l|l|c|c|c|l|}
\hline SI. No. & Species & $\begin{array}{l}\text { Registered } \\
\text { Breeds }\end{array}$ & $\begin{array}{l}\text { Population in 2019 } \\
\text { (in millions) }\end{array}$ & $\begin{array}{l}\text { Growth \% } \\
\text { (over 2012) }\end{array}$ & $\begin{array}{l}\text { Ranking } \\
\text { (World) }\end{array}$ & Top state \\
\hline $\mathbf{1 .}$ & Cattle & 50 & 192.49 & 0.83 & 1 & West Bengal \\
\hline $\mathbf{2 .}$ & Buffaloes & 17 & 109.85 & 1.06 & 1 & Uttar Pradesh \\
\hline $\mathbf{3 .}$ & Sheep & 44 & 74.26 & 14.13 & 3 & Telangana \\
\hline $\mathbf{4 .}$ & Goats & 34 & 148.88 & 10.14 & 2 & Rajasthan \\
\hline $\mathbf{5 .}$ & Pigs & 10 & 9.06 & -12.03 & & Assam \\
\hline $\mathbf{6 .}$ & Camel & 09 & 0.25 & -37.05 & & Rajasthan \\
\hline $\mathbf{7 .}$ & Horse \&Ponies & 07 & 0.34 & -45.58 & & Uttar Pradesh \\
\hline $\mathbf{8 .}$ & Mules & - & 0.08 & -57.09 & & Uttarakhand \\
\hline $\mathbf{9 .}$ & Donkey & 03 & 0.12 & -61.23 & & Arusthan \\
\hline $\mathbf{1 0 .}$ & Mithun & - & 0.38 & 26.66 & & Jammu \& Kashmir \\
\hline $\mathbf{1 1 .}$ & Yak & 01 & 0.06 & -25.00 & & Uttar Pradesh \\
\hline Total livestock & 197 & 535.78 & 4.63 & & Tamil Nadu \\
\hline Total poultry & 19 & 851.81 & 16.8 & 7 (Chicken) & \\
\hline
\end{tabular}

Table 2: Livestock Population - Major Species of Goa

\begin{tabular}{|l|c|c|c|}
\hline Species & Male & Female & Total \\
\hline Cattle (indigenous) & 11583 & 32718 & 60220 \\
\hline Cattle (exotic/cross) & 1619 & 25883 & 27502 \\
\hline Buffalo & 4861 & 22346 & 27207 \\
\hline Pig (exotic/cross) & 1762 & 2064 & 3826 \\
\hline Pig (indigenous) & 15659 & 15995 & 35480 \\
\hline Sheep & - & - & 662 \\
\hline Goat & 3108 & 6338 & 9446 \\
\hline Horse & 7 & 8 & 15 \\
\hline Camel & 2 & - & 2 \\
\hline Poultry (backyard) & 27594 & 8803 & 52412 \\
\hline Ducks & - & - & 1024 \\
\hline
\end{tabular}

Source- Livestock census, DAHD, 2019 


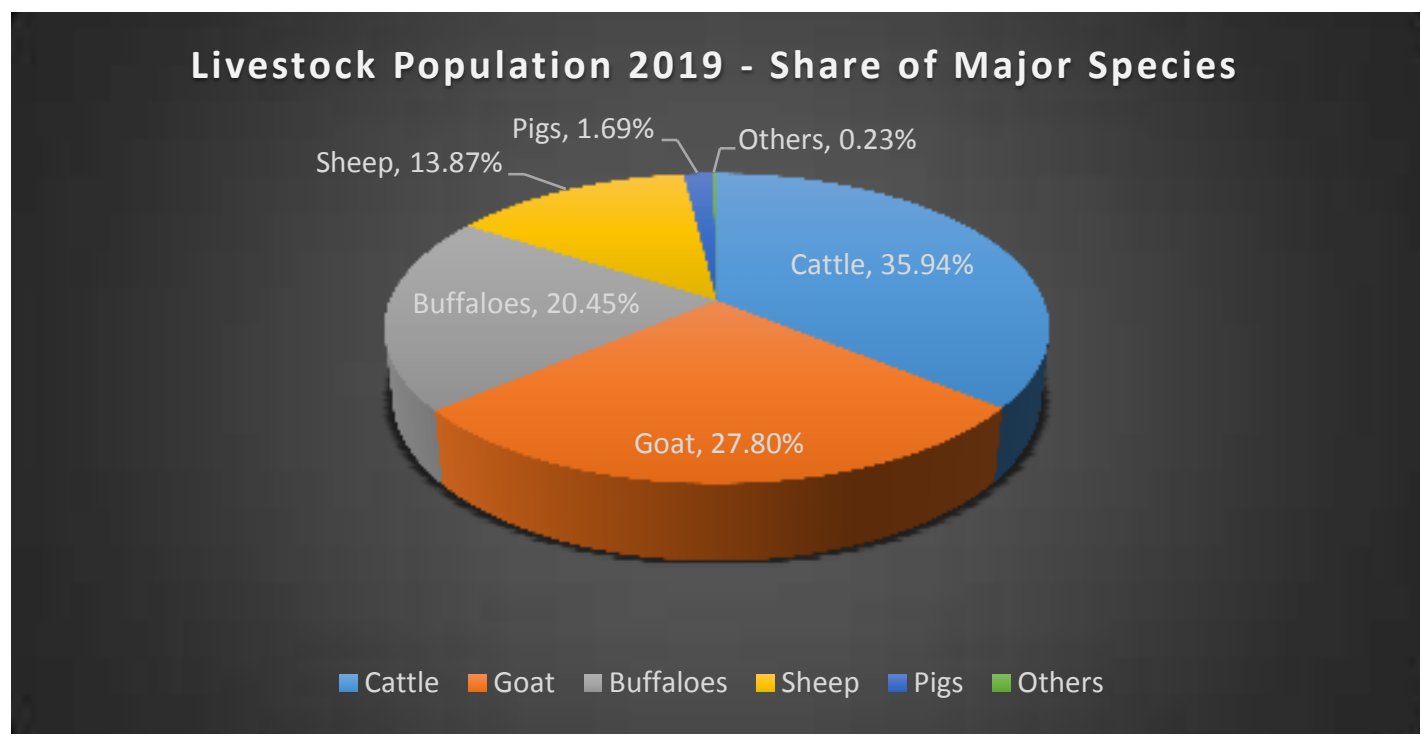

Fig 1: Per cent contribution of different livestock species in India (Livestock census, DAHD, 2019)

\section{Cattle Breeds of Goa}

\section{KONKAN KAPILA}

Synonyms: Konkan Gidda, Konkan

Breeding tract: The breed name is given as it is found in Konkan area of Maharashtra and Goa and "KAPILA" as per the Indian mythology. The native tract is Konkan region, Raigadh, Sindhudurg, Thane, Ratnagiri, Palghar districts of Maharashtra and Goa.

Morphological characters: It is small and compact size animal with small parallel ears and straight forehead. The usual colour is brown to black. But it also found in white, grey, brown, black and mixed. The horns emerges from side and behind the pole region which are short going outward backward and upward direction with pointed tips. Height of animal is $105 \mathrm{~cm}$ and $100 \mathrm{~cm}$ of male and female respectively. Singh et al., 2019 reported that weight is around $240 \mathrm{~kg}$ and $225 \mathrm{~kg}$ of male and female respectively. An Adult male and an adult female of Konkan Kapila cattle is shown in Figure 2a, 2b (Source: http://14.139.252.116/hKKapila.html).

Economic characters: It yields $450 \mathrm{~kg}$ in total lactation with daily $2.23 \mathrm{~kg}$. Fat $\%$ is reported average $4.55 \%$ but in some animal it also goes up to $7.5 \%$. Singh et al., 2019 reported that average age at first calving is 49.27 months (ranges between 30 to 60 months). He also reported that average calving interval of Konkan Kapila cattle is 17.21 months (ranging from12 to 18 months). Mainly it is useful for draught purpose in Konkan region and only source of milk in that region.

Population: 600000 (AHVS, Goa, 2012)

\section{SHWETA KAPILA}

Synonyms: Gaunthi, Gavthi Dhavi

Breeding tract: The breed name is given as it is found in complete white colour. The native tract is whole Goa region. Found on different districts of North and South Goa.

Morphological characters: It is small to medium size animal with straight forehead. It is found exclusively in White (SHWETA) colour with whitish-brown eyelashes and muzzle. The horns are curved medium in size going backward and upward direction with pointed tips. Height of animal is $113 \mathrm{~cm}$ and $107 \mathrm{~cm}$ of male and female respectively. Weight is around $383 \mathrm{~kg}$ and $277 \mathrm{~kg}$ of male and female respectively as reported by NBAGR, 2019 (URL: www.nbagr.res.in). An Adult male and an adult female of Shweta Kapila cattle is shown in Figure 3a, 3b (Source: http://14.139.252.116/Shweta_Kapila.html).

Economic characters: It yields $510 \mathrm{~kg}$ in total lactation with maximum up to $650 \mathrm{~kg}$. Fat\% is reported average $5.21 \%$ but in some animal it also goes up to $6.4 \%$. Age at first calving ranges between 35 to 58 months. Calving interval is about 13 to 17 months (NBAGR, 2019; URL: www.nbagr.res.in). It is mainly used for milk purpose only. It is believed in North-Goa that milk of SHWETA KAPILA has medicinal properties. It is also resistant in heavy rainfall. So it has unique characteristics which can be used in future for research purpose.

Population: 39777 (AHVS, Goa, 2012) 
Fig 2: Konkan Kapila Cattle Breed; 2a: Adult male; 2b: Adult female

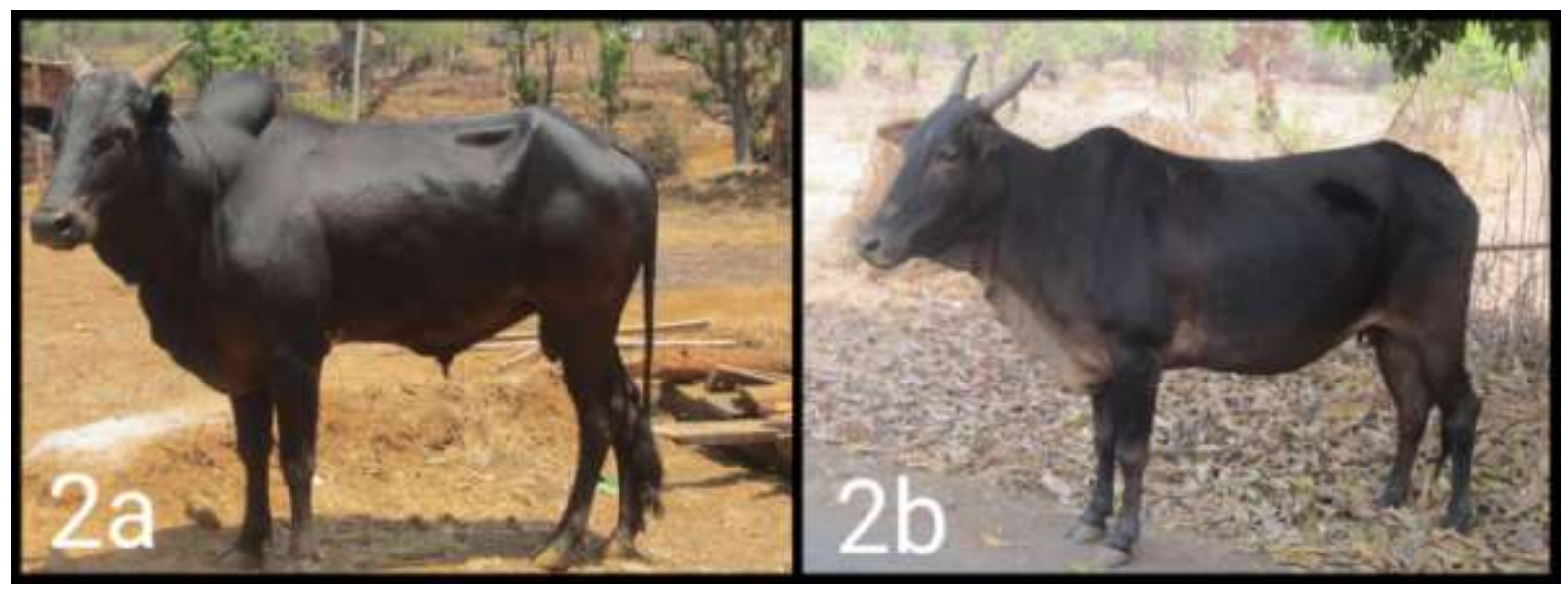

Fig 3: Shweta Kapila Cattle Breed; 3a: Adult male; 3b: Adult female

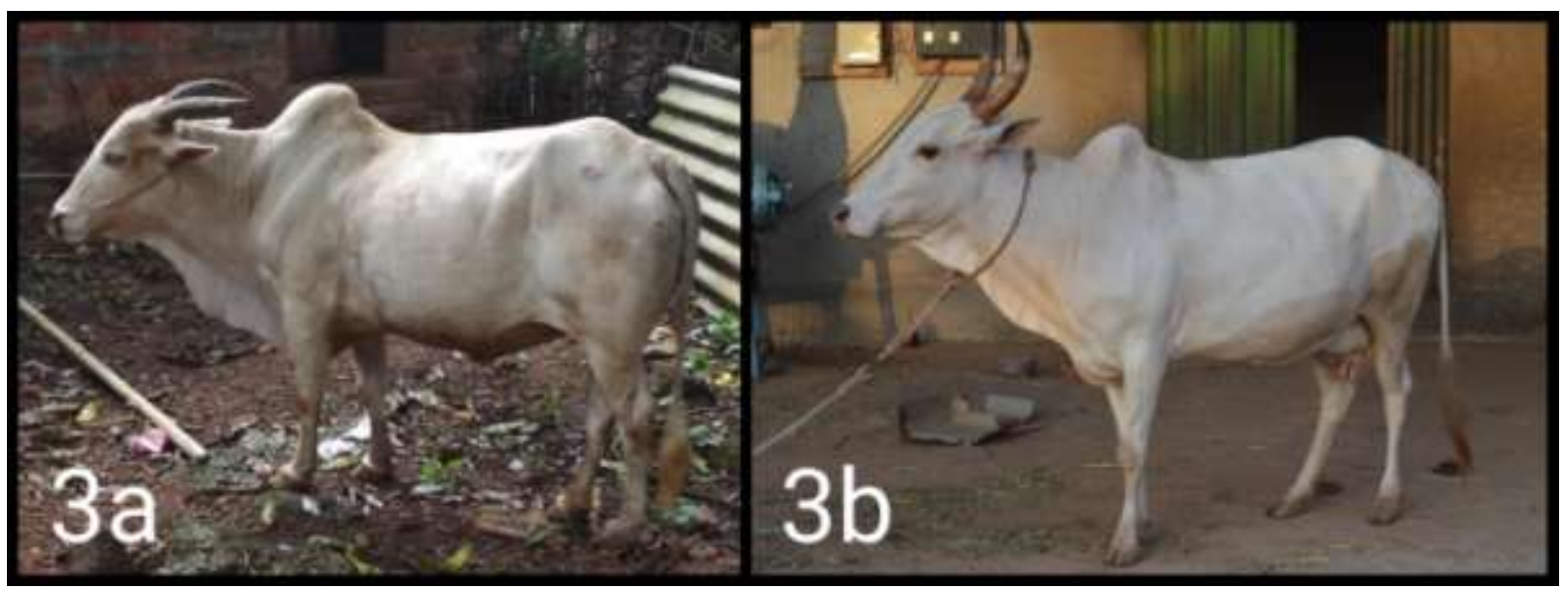

\section{Pig Breeds of Goa}

\section{AGONDA GOAN}

Synonyms: Gavthi Dukor

Breeding tract: The breed name is given on the name of AGONDA village of Goa. The native tract is Tiswadi, Bardez and Ternem of North-Goa district and Mormugao, Salcete, Canacona, Quepemtalukas of South-Goa district.

Morphological characters: It is wild in nature with small and compact size. The usual colour is black. But it also found with white patches on legs and face. The legs and snouts are small. Bristles are rough. Height of animal is $55 \mathrm{~cm}$ and $60 \mathrm{~cm}$ of male and female respectively. Weight is around $41 \mathrm{~kg}[38.91 \pm 5.71 \mathrm{~kg}$ (Chakurkar et al., 2016)] and $43 \mathrm{~kg}$ of male and female respectively. An Adult male and an adult female of Agonda Goan cattle is shown in Figure 4a, 4b (Source: http://www.nbagr.res.in/Agonda.html).

Economic characters: It has $72 \%$ dressing percentage. Age at first calving ranges between 7 to 14 months. Calving interval is 5.2 to 6.6 months. Litter size it average 7.45 with range of 2 to 13 . Slaughter age is 6 to 8 months with 65-67 kg live weight (NBAGR, 2019; URL: www.nbagr.res.in). Mainly used for Pork and sausages known as "Chouris" as only pork of this breed is preferred by the people of Goa. Manure is also used for horticulture. Important for future aspect as it requires low maintenance and it has exceptional mothering instinct. Population: 37556 (AHVS, Goa, 2012) 
Fig 4: Agonda Goan Pig Breed; 4a: Adult male; 4b: Adult female

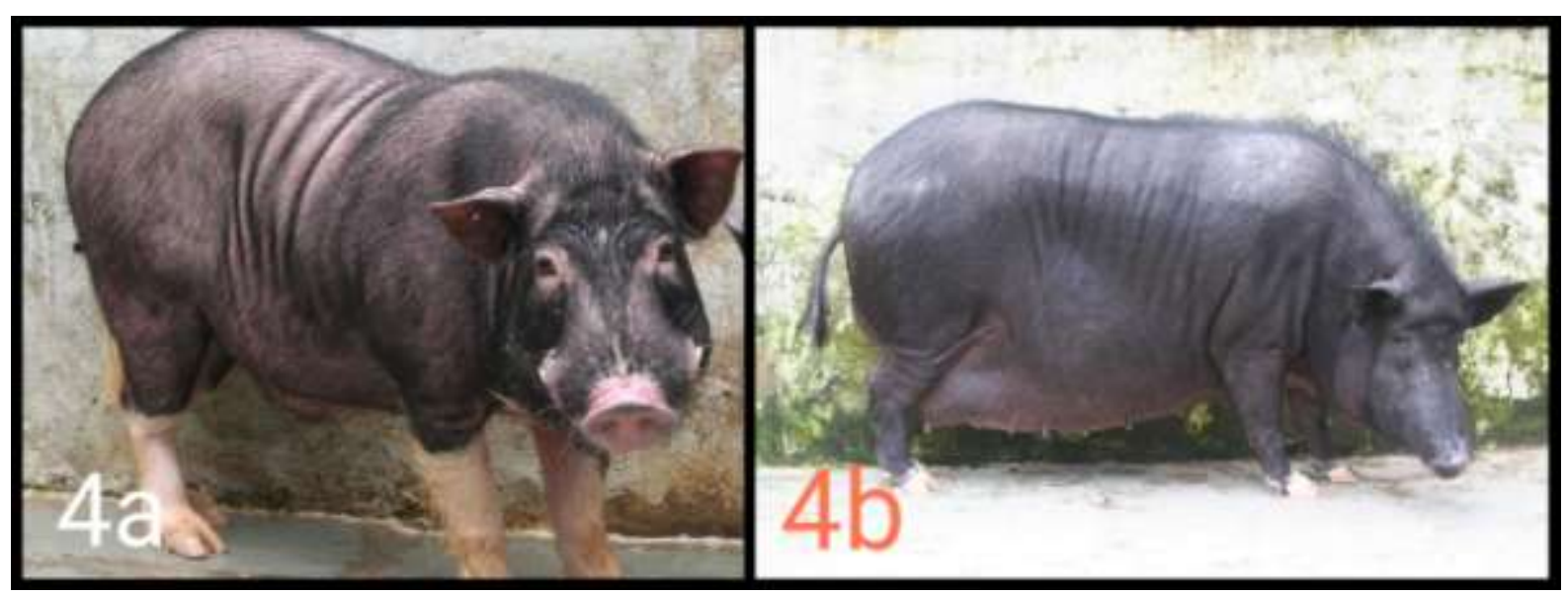

\section{Conclusion}

Goa is contributing to Indian animal genetic resources with only three breeds of livestock but the characteristics of these breeds are unique and having great importance. These characteristics are divergent from the other animal genetic resources, hence can be used for the future research purpose and various breeding programmes for genetic improvement of the country's genetic resources.

\section{References}

1) AHVS, 2012. Directorate of Animal Husbandry and Veterinary Services, Government of Goa, Panaji, Goa, 2012. Browsed from URL: https://ahvs.goa.gov.in/

2) Chakurkar, E. B., Naik, S. S., Barbuddhe, S. B., Karunakaran, M., Naik, P. K. And Singh, N. P., 2016. Seminal attributes and sperm morphology of Agonda Goan pigs. Journal of Applied Animal Research. 44(1): 130-134.

3) Chaudhry, P., Dollo, M., Bagra, K. And Yakang, B., 2011. Traditional biodiversity conservation and natural resource management system of some tribes of Arunachal Pradesh, India. Interdisciplinary Environmental Review. 12(4): 338-348.

4) CI, 1998. Megadiversity: The 17 Biodiversity Superstars, Conservational International, Arlington, USA.

5) DAHD (2019). 20th Livestock Census-2019 All India Report. Published by Department of Animal Husbandry and Dairying (AH\&D), Ministry of Fisheries, Animal Husbandry \& Dairying, Government of India. Browsed from URL: https://dahd.nic.in/about-us/divisions/statistics

6) NBAGR, 2019. National Bureau of Animal Genetic Resources, Karnal, India. Browsed from URL: www.nbagr.res.in

7) Office of the Registrar General \& Census Commissioner, India, 2020. Browsed from URL: https://censusindia.gov.in/census_data_2001/india_at_glance/area.aspx

8) Singh, P.K., Pundir, R.K., Dangi, P.S., Desai, B.G., Bhagat, D.J. and Kumar, S., 2019. Physical features, management and performance of Konkan cattle. The India Journal of Animal Sciences. 89(4): 413-418.

9) Unique identification Aadhar India, 2020. Browsed from URL: https://uidai.gov.in/images/ state- wiseaadhaar-saturation.pdf 